\title{
Associated fauna and effects of epibiotic barnacles on the relative growth and reproductive indices of Stramonita haemastoma (Gastropoda: Muricidae)
}

\author{
Tahani El Ayari, Youssef Lahbib, Najoua Trigui El Menif \\ University of Carthage, Faculty of Sciences of Bizerta, Laboratory of Environment Bio-monitoring, 7021- Zarzouna, \\ Bizerta, Tunisia. E-mail: najoua.trigui.elmenif@gmail.com
}

\begin{abstract}
Summary: To better understand the impacts of biofouling on the biological processes of the basibiont, the effects of epibiotic barnacles on the relative growth and reproductive indices of Stramonita haemastoma (Linnaeus, 1767) were assessed. A total of 1035 specimens were collected monthly for one year from Bizerta Channel (northern Tunisia). Endobiotic species comprised the lithophagous bivalves Lithophaga aristata and Rocellaria dubia of different sizes, communicating with the outside through tiny perforations. Intra-shell tunnels and galleries also sheltered annelids and sipunculids. Epibiotic species comprised algae and highly diversified invertebrates represented by crustaceans, polychaetes, molluscs, echinoderms, ascidians, sponges, bryozoans and sipunculids, with barnacles being the most common group. Comparison of growth features between non-fouled and fouled S. haemastoma revealed higher growth in non-fouled specimens. Differences in reproductive condition indices were detected in few months, being mostly higher in non-fouled snails, but showed no asynchrony in the spawning period for either fouled or non-fouled gastropods hosts.
\end{abstract}

Keywords: Stramonita haemastoma; biofouling; reproductive indices; relative growth; Bizerta Channel.

Fauna asociada y efecto de los balanos epibiontes al crecimiento relativo e índices reproductivos de Stramonita haemastoma (Gasterópoda: Muricidae)

Resumen: Para mejorar la compresión de los impactos del biofouling en los procesos biológicos de los basibiontes, se ha evaluado los efectos de los balanos epibiontes en el crecimiento relativo y en los índices reproductivos de Stramonita haemastoma (Linnaeus, 1767). Se recogieron un total de 1032 especímenes mensualmente, durante un año, en el canal de Bizerta (norte de Túnez). Las especies endobióticas estaban compuestas por los bivalvos litófagos Lithophaga aristata y Rocellaria dubia, de diferentes tamaños, que se comunicaban con el exterior a través de pequeñas perforaciones. Los túneles y galerías del interior de la concha también albergaban anélidos y sipuncúlidos, siendo los balanos el grupo más común. La comparación del crecimiento entre los gasterópodos con y sin fouling mostró un mayor crecimiento en los S. haemastoma sin fouling. Las diferencias en los índices reproductivos se detectaron en pocos meses, siendo mayor en los caracoles no invadidos por el fouling, pero ninguno de los gasterópodos hospedadores mostró asincronía en el periodo de desove.

Palabras clave: Stramonita haemastoma; biofouling; índices reproductivos; crecimiento relativo; canal de Bizerta.

Citation/Como citar este artículo: El Ayari T., Lahbib Y., Trigui El Menif N. 2015. Associated fauna and effects of epibiotic barnacles on the relative growth and reproductive indices of Stramonita haemastoma (Gastropoda: Muricidae). Sci. Mar. 79(2): 223-232. doi: http://dx.doi.org/10.3989/scimar.04151.18A

Editor: M.B. Gaspar.

Received: September 22, 2014. Accepted: March 6, 2015. Published: April 27, 2015.

Copyright: (c) 2015 CSIC. This is an open-access article distributed under the Creative Commons Attribution-Non Commercial Lisence (by-nc) Spain 3.0.

\section{INTRODUCTION}

The mollusc shell is a suitable biotope for the settlement and development of several groups of invertebrates. In molluscs, biofouling has mainly been described in bivalves such as Pinna bicolor (Keough 1984), Chlamys opercularis (Ward and Thorpe 1991),
Crassostrea gigas (Duault et al. 2001), Venus verrucosa (Trigui El Menif et al. 2005), Flexopecten felipponei (Schejter and Bremec 2006), Lithophaga lithophaga (Trigui El Menif et al. 2007) and Pinna nobilis (Rabaoui et al. 2009). The associated fauna highlighted in these bivalve species belongs to several zoological groups: bryozoans, annelids, serpulid polychaetes, tu- 
nicates, sponges, crustaceans, ascidians, cnidarians and echinoderms.

Few studies have as yet dealt with shell fouling and its effects in gastropods. These include the study by Buschbaum and Reise (1999) reporting the effects of barnacle colonization on the shell of Littorina littorea and those of Bick (2006) and Vasconcelos et al. (2007) on polychaete fixation in the shells of Stramonita haemastoma and Hexaplex trunculus, respectively.

Few studies of the biology of S. haemastoma have been published, and they deal mainly with reproduction, spawning and intracapsular development (Beliste and Stickle 1978, Lahbib et al. 2011). The most studied aspect in $S$. haemastoma is the imposex phenomenon (Spence et al. 1990, Rilov 1999, Lemghich and Benajiba 2007, Lahbib et al. 2010, El Ayari et al. 2015), the sexual deformity associated with marine pollution by organotin compounds such as tributyltin (TBT) and its derivatives (Terlizzi et al. 2001). Recently, the effect of epibiotic barnacles on imposex in $S$. haemastoma sampled from Tunisian coasts was investigated (El Ayari et al. 2015).

Taking into consideration the well-known effects of biofouling that could possibly affect the biology of the basibiont, the present study aimed to identify species associated with the shell of $S$. haemastoma from Tunisian waters and to investigate whether this fouling could affect the relative growth and reproductive indices of this locally abundant gastropod species.

\section{MATERIALS AND METHODS}

Specimens of $S$. haemastoma with a shell length of $20-80 \mathrm{~mm}$ were collected monthly $(\mathrm{N}=80-120)$ on a rocky bottom from June 2009 to May 2010. Sampling was performed by scuba diving at $11 \mathrm{~m}$ depth at a station located in the artificial channel linking the Bizerta lagoon with the Mediterranean Sea (Fig. 1). Seawater temperature and salinity were measured using a multiparameter sounder. In the laboratory, fauna living on the shell external surface was collected by washing the shells using seawater from the same sampling station.

Comparison of relative growth and reproductive indices in S. haemastoma was investigated monthly in two groups: 40 to 60 gastropods non-fouled by barnacles (GnFB) and 40 to 60 gastropods fouled by barnacles (GFB). The position and number of barnacles per individual were determined after removing them from the shells of the hosts using a scalpel. Gastropods were then sacrificed by freezing at $-20^{\circ} \mathrm{C}$; shell length (SL), shell diameter (SD), and penis length (PL) were measured to the nearest $0.1 \mathrm{~mm}$ using a digital caliper. After thawing, the shell was broken using a bench vice and the soft part of the organism was carefully removed. Endobiotic fauna was collected after shell breakage, identified following macroscopic observation or under a binocular microscope, and then preserved in $70 \%$ alcohol.

In $S$. haemastoma, three gonad maturation stages were detected following macroscopic observations of the gonads in both sexes and of the capsule gland in females, following Ramón and Amor (2002) in the sympatric muricid Bolinus brandaris. Stage I (immature) corresponds to undifferentiated gonads from the underlying capsule gland in both sexes and females having an inconspicuous capsule gland; stage II (intermediate) gonads in both sexes are more developed and correspond approximately to one-third of the area of the digestive gland; and stage III (mature) males show a well-developed, light brown testicle corresponding to more than half of the area of the digestive gland, whereas females have a voluminous yellowish ovary and a large yellowish capsule gland.

The flesh wet weight $(\mathrm{FwW})$ was recorded after removing the operculum. The female capsule gland was separated and weighed $(\mathrm{CGwW})$. A cross-section was made on the coiled part of the organism, directly under the stomach, and was photographed to measure the gonad area (GA) and the area of the digestive glandgonad complex (DGGA) using the software Image $\mathrm{J}$ $1.38 \mathrm{x}$. The shell dry weight (SdW) and the flesh dry weight $(\mathrm{FdW})$ were recorded after drying them at $60^{\circ} \mathrm{C}$ for 3 days.

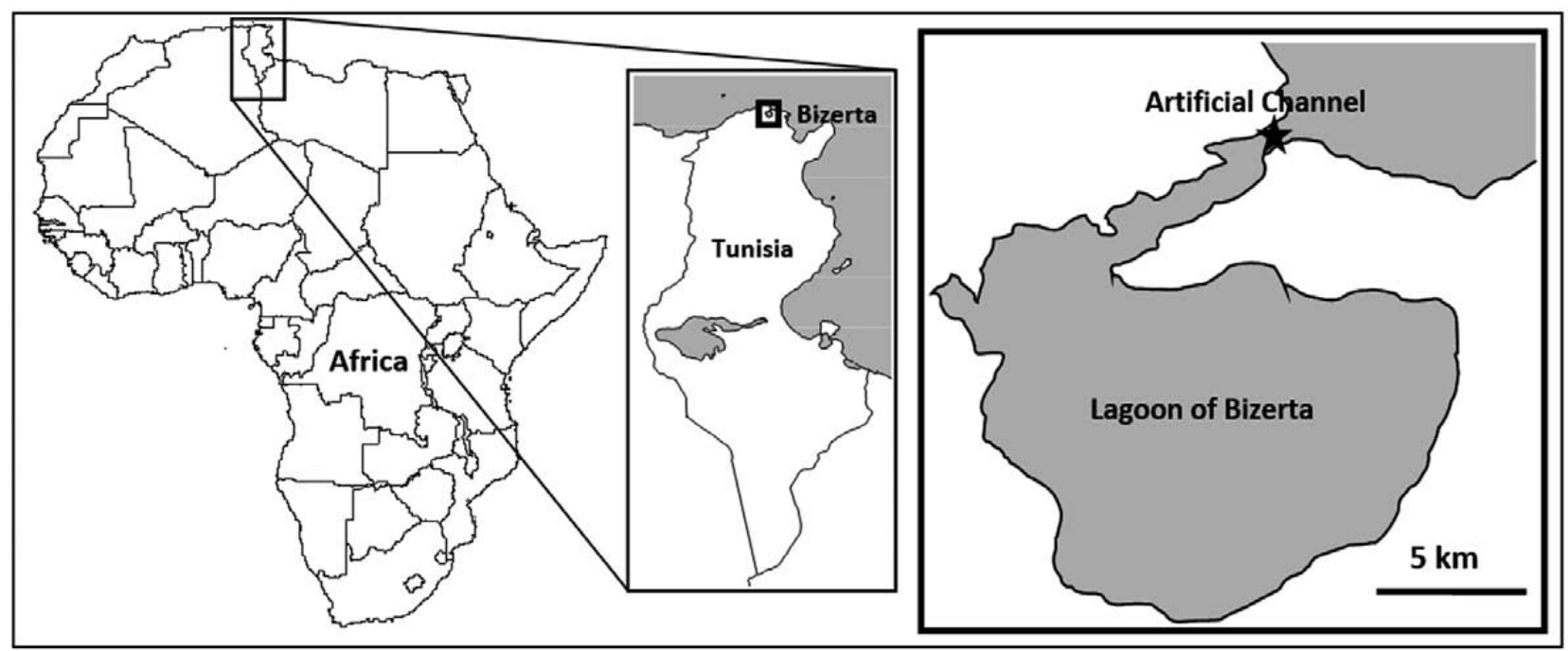

Fig. 1. - Map of Tunisia and sampling site of Stramonita haemastoma in the channel of Bizerta. 
Table 1. - Monthly seawater temperature and salinity values recorded in Bizerta Channel during the study period (June 2009 - May 2010).

\begin{tabular}{lcccccccccccc}
\hline & $\mathrm{J}$ & $\mathrm{J}$ & $\mathrm{A}$ & $\mathrm{S}$ & $\mathrm{O}$ & $\mathrm{N}$ & $\mathrm{D}$ & $\mathrm{J}$ & $\mathrm{F}$ & $\mathrm{M}$ & $\mathrm{A}$ & $\mathrm{M}$ \\
\hline Temperature $\left({ }^{\circ} \mathrm{C}\right)$ & 24.5 & 25.7 & 26.7 & 24.4 & 20.3 & 14.0 & 16.0 & 15.2 & 14.0 & 13.3 & 17.0 & 23.9 \\
Salinity & 35.8 & 36.7 & 37.2 & 37.9 & 36.7 & 27.6 & 23.1 & 23.9 & 28.5 & 29.3 & 28.0 & 31.1 \\
\hline
\end{tabular}

The reproductive condition of $S$. haemastoma was assessed using the following indices, expressed as percentages:

- Gonadosomatic index (GSI) = digestive glandgonad complex dry weight/SdW (Lucas and Beninger 1985);

- Capsule gland index (CGI) = CGwW/FwW (Giménez and Penchaszadeh 2003);

- Gonad area index (GAI) = GA/DGGA (Poore 1973);

- Penial index $(\mathrm{PI})=$ PL/SL (Vasconcelos et al. 2011).

Relationships between morphometric and ponderal variables (SL, SD, SdW and FdW) were established through regression analysis $\left(\mathrm{Y}=\mathrm{aX} \mathrm{X}^{\mathrm{b}}\right)$. Relative growth between variables was determined by comparing the regression slopes (b) using the Student t-test (Mayrat 1959). A chi-square test was employed to verify a balanced proportion $(1 \mathrm{M}: 1 \mathrm{~F})$ in the sex ratio of the samples. Comparisons between fouled and non-fouled gastropods were made through analysis of covariance (ANCOVA - model of homogeneity of slopes) using the software STATISTICA 10, with the covariable being always SL. Post-hoc pairwise comparisons were made using the Tukey test. Monthly variations in bio-physiological indices were analysed by one-way ANOVA (Kruskal-Wallis test). In all statistical analysis, significance level was considered for $\mathrm{P}<0.05$

\section{RESULTS}

\section{Seawater temperature and salinity}

The average seawater temperature measured in Bizerta Channel during the study period (June 2009 to May 2010) was $19.6^{\circ} \mathrm{C}$. The lowest temperature $\left(13.3^{\circ} \mathrm{C}\right)$ was recorded in March and the highest $\left(26.7^{\circ} \mathrm{C}\right)$ in $\mathrm{Au}-$ gust (Table 1). The salinity reached a maximum (37.9) in September and a minimum (23.1) in December (Table 1), corresponding to an average value of 31.3 .

\section{Population sex ratio}

The sex ratio of the studied population showed a higher abundance of males in both fouled and nonfouled gastropods. Unbalanced sex ratios were only statistically significant in the monthly samples of April for GFB $\left(\chi^{2}=4.07, \mathrm{P}<0.05\right)$ and of December for GnFB $\left(\chi^{2}=4.57, \mathrm{P}<0.05\right)$.

\section{Associated fauna}

Among a total of 1035 individuals of S. haemastoma with an average length of $53.4 \pm 6.7 \mathrm{~mm}$, an abundant and very diversified associated fauna and flora was identified, composed mainly of crustaceans, polychaetes, molluscs, echinoderms, ascidians, sponges,

Table 2. - Fauna associated with Stramonita haemastoma collected from Bizerta Channel (northern Tunisia).

\begin{tabular}{|c|c|c|c|c|c|}
\hline & Epibiotic species & Endobiotic species & & Epibiotic species & Endobiotic species \\
\hline \multirow[t]{9}{*}{ Mollusca } & GASTROPODA & BIVALVIA & Errant & SYLLIDAE & \\
\hline & Diodora graeca & Lithophaga aristata & Polychaetes & Syllis amica & \\
\hline & Diodora sp. & Rocellaria dubia & & Streptoyllis sp. & \\
\hline & Patella sp. & & & EUNICIDAE & \\
\hline & Acmaea insessa & & & Eunice vitatta & \\
\hline & BIVALVIA & & & Lysidice ninetta & \\
\hline & Anomia ephippium & & & Hyalinoecia bilineata & \\
\hline & Grassostrea gigas & & & NEREIDAE & \\
\hline & Ostrea edulis & & & Perinereis cullrifera & \\
\hline \multirow[t]{20}{*}{ Crustacea } & SESSILIA & Acrothoracica & & Nereis rava & \\
\hline & Balanus amphitrite & Unidentified & & PHYLLODOCIDAE & \\
\hline & Balanus perforatus & & & Eullalia sp. & \\
\hline & AMPHIPODA & & & CHRYSOPETALIDAE & \\
\hline & Gammarus aequicauda & & & Chrysopetalum debile & \\
\hline & Gammarus marinus & & & SPHAERODARIDAE & \\
\hline & Gammarus insensibilis & & & Sphaerosyllis pirifera & \\
\hline & Gammarus pulex & & Sedentary & SERPULIDAE & CIRRATULIDAE \\
\hline & Gammarus chevreuxi & & Polychaetes & Pomatoceros triqueter & Dodecaceria concharum \\
\hline & Gammarus olivii & & & Hydroides uncinata & Audonia tentaculata \\
\hline & Gammarus locusta & & & Hydroides diramphus & Heterocirrus sp. \\
\hline & Elasmopus rapax & & & Serpula concharum & SPIONIDAE \\
\hline & DECAPODA & & & Serpula vermicularis & Pygospio elegens \\
\hline & Achaeus cranchi & & & SABELLIDAE & Polydora sp. \\
\hline & Acanthonyx lunulatus & & & Sabella sp. & LUMBRINERIDAE \\
\hline & Xantho poressa & & & & Lumbrinereis sp. \\
\hline & ISOPODA & & Sipunculoidea & & PHASCOLOSOMATIDAE \\
\hline & $\begin{array}{l}\text { Cymodoce sp. } \\
\text { PYCNOGONIDA }\end{array}$ & & & & $\begin{array}{l}\text { Phascolosoma stephensoni } \\
\text { ASPIDOSIPHONIDAE }\end{array}$ \\
\hline & Achelia sp. & & & & $\begin{array}{l}\text { Aspidosiphon muelleri } \\
\text { Phascolosoma } \mathrm{sp}\end{array}$ \\
\hline & & & Echinodermata & $\begin{array}{l}\text { Amphipholis squamata } \\
\text { Ophiopsila aranea } \\
\text { Ophiura sp. }\end{array}$ & \\
\hline
\end{tabular}



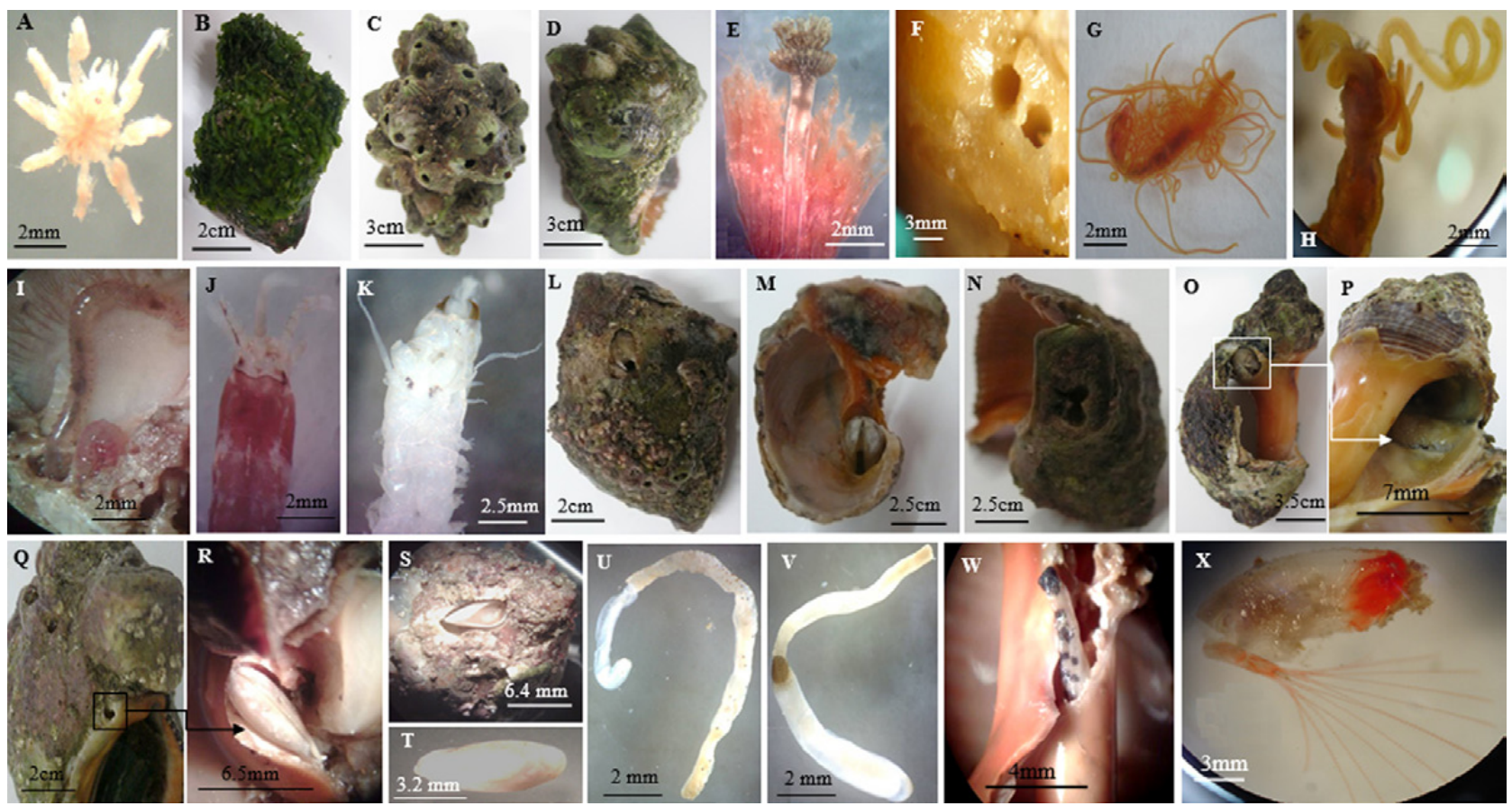

Fig. 2. - Fauna associated with S. haemastoma. A, Achelia sp. found in the external shell surface of S. haemastoma; B, shell of S. haemastoma covered by green algae; $\mathrm{C}$, barnacles entirely covering the gastropod shell; $\mathrm{D}$, oysters randomly distributed on the gastropod shell; $\mathrm{E}$, Hydroides diramphus removed from white tube in the shell of $S$. haemastoma; $\mathrm{F}$, shell perforation caused by annelids; G, unidentified cirratulid; $\mathrm{H}$, Dodecaceria concharum removed from intra-shell gallery; I, J, K, errant polychaetes (Aponuphis bilineata and Perinereis cullrifera) removed from tunnels in the shell of S. haemastoma; L, Lithophaga aristata in gallery on the dorsal side of the shell; M, L. aristata in gallery located in the direction "apical axis-siphonal canal"; N, eight-shaped hole showing the penetration of $L$. aristata; $\mathrm{O}, \mathrm{P}, \mathrm{Q}$, penetration of $L$. aristata in perpendicular direction to the apical axis; $\mathrm{R}, L$. aristata reached the visceral mass; S, T, Rocellaria dubia removed from breach dug in the last spire of the shell; U, Phascolosoma sp. found in gallery in the dorsal surface near the last spire of the host shell; V, Aspidosiphon muelleri muelleri removed from a gallery in the dorsal surface; W, Phascolosoma stephensoni removed from a gallery located on the edge of the columella; X, unidentified crustacean (Acrothoracica sp.) removed from intra-shell cavity with $3 \mathrm{~mm}$.
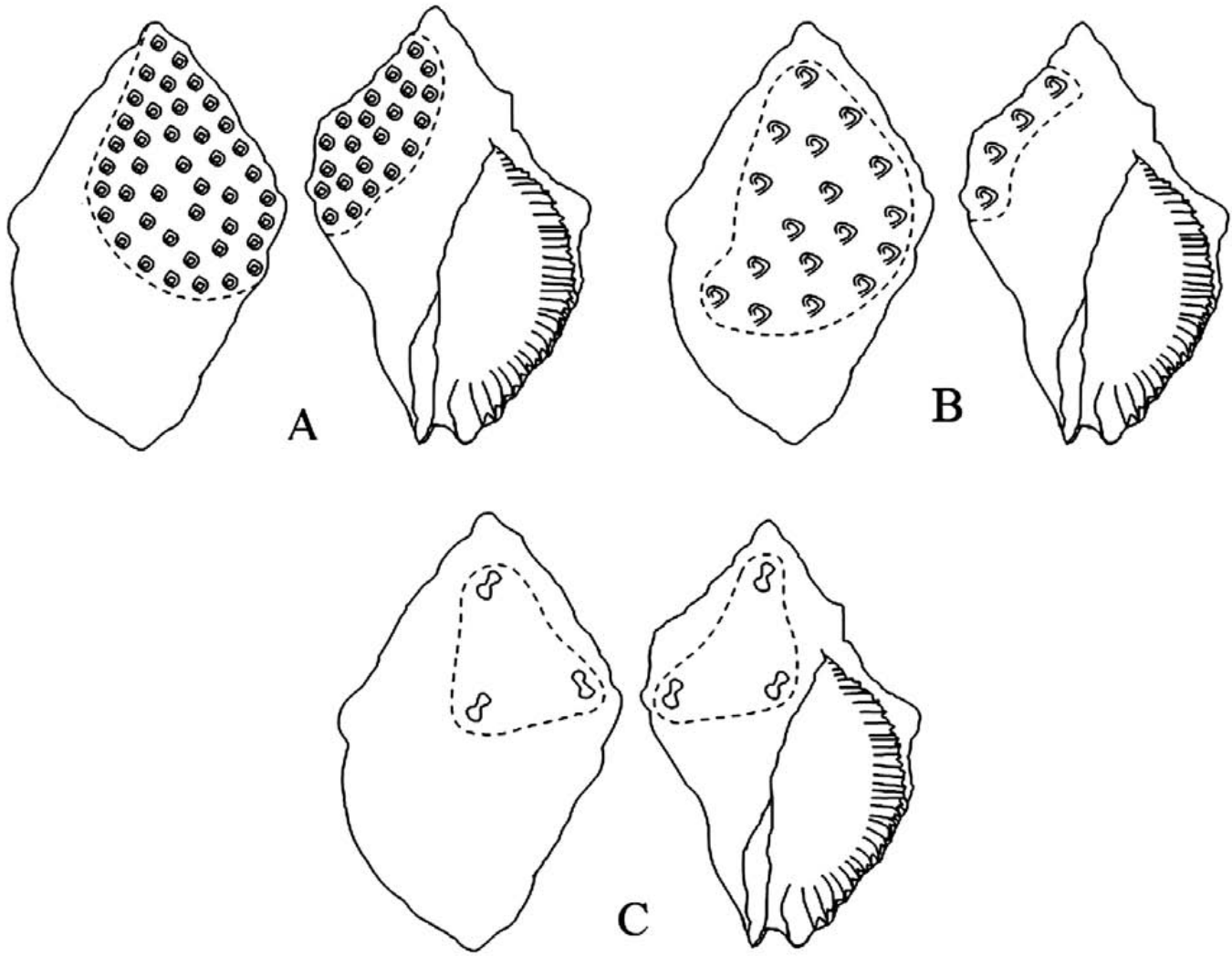

Fig. 3. - Preferential shell colonization zone/location of epibiotic species observed in the shells of heavily fouled S. haemastoma; (A) barnacles; (B) polychaete tubes; (C) perforations caused by Lithophaga aristata. 
Table 3. - Relative growth of non-fouled and fouled S. haemastoma (sexes confounded and separate sexes). SL, shell length; SD, shell diameter; SdW, Shell dry weight; FdW, Flesh dry weight; N, number of individuals; M, males; F, females; r, correlation coefficient; t, Student t-test.

\begin{tabular}{|c|c|c|c|c|}
\hline Biometric variables & \multicolumn{2}{|c|}{$\begin{array}{l}\text { Gastropod non-fouled by barnacles (both sexes) } \\
\qquad(\mathrm{N}=439)\end{array}$} & \multicolumn{2}{|c|}{$\begin{array}{l}\text { Gastropod fouled by barnacles (both sexes) } \\
\qquad(\mathrm{N}=596)\end{array}$} \\
\hline $\mathrm{SD} / \mathrm{SL}$ & \multicolumn{2}{|c|}{$\begin{array}{c}\mathrm{SD}=0.58 \mathrm{SL}^{1.02} \\
\mathrm{r}=0.95 \mathrm{t}=2.48\end{array}$} & \multicolumn{2}{|c|}{$\begin{array}{l}\mathrm{SD}=0.75 \mathrm{SL}^{0.95} \\
\mathrm{r}=0.94 \mathrm{t}=4.63\end{array}$} \\
\hline $\mathrm{SdW} / \mathrm{SL}$ & \multicolumn{2}{|c|}{$\begin{array}{l}\mathrm{SdW}=5 \mathrm{E}-03 \mathrm{SL}^{2.63} \\
\mathrm{r}=0.93 \mathrm{t}=22.20\end{array}$} & \multicolumn{2}{|c|}{$\begin{array}{c}\mathrm{SdW}=5 \mathrm{E}-05 \mathrm{SL}^{2.55} \\
\mathrm{r}=0.76 \mathrm{t}=19.81\end{array}$} \\
\hline FdW/SL & \multicolumn{2}{|c|}{$\begin{array}{l}\mathrm{FdW}=9 \mathrm{E}-06 \mathrm{SL}^{3.07} \\
\mathrm{r}=0.88 \mathrm{t}=24.04\end{array}$} & \multicolumn{2}{|c|}{$\begin{array}{c}\mathrm{FdW}=6 \mathrm{E}-05 \mathrm{SL}^{2.60} \\
\mathrm{r}=0.78 \mathrm{t}=157.23\end{array}$} \\
\hline Sexes & $\mathrm{M}(\mathrm{N}=241)$ & $\mathrm{F}(\mathrm{N}=198)$ & $\mathrm{M}(\mathrm{N}=331)$ & $\mathrm{F}(\mathrm{N}=265)$ \\
\hline $\mathrm{SD} / \mathrm{SL}$ & $\begin{array}{l}\mathrm{SD}=0.59 \mathrm{SL}^{1.01} \\
\mathrm{r}=0.95 \mathrm{t}=1.50\end{array}$ & $\begin{array}{c}\mathrm{SD}=0.56 \mathrm{SL}^{1.03} \\
\mathrm{r}=0.95 \mathrm{t}=0.19\end{array}$ & $\begin{array}{c}\mathrm{SD}=0.76 \mathrm{SL}^{0.95} \\
\mathrm{r}=0.95 \mathrm{t}=3.78\end{array}$ & $\begin{array}{l}\mathrm{SD}=0.74 \mathrm{SL}^{0.96} \\
\mathrm{r}=0.93 \mathrm{t}=2.60\end{array}$ \\
\hline $\mathrm{SdW} / \mathrm{SL}$ & $\begin{array}{l}\mathrm{SdW}=6 \mathrm{E}-03 \mathrm{SL}^{2.57} \\
\mathrm{r}=0.94 \mathrm{t}=13.45\end{array}$ & $\begin{array}{l}\mathrm{SdW}=3 \mathrm{E}-03 \mathrm{SL}^{2.73} \\
\mathrm{r}=0.93 \mathrm{t}=1.55\end{array}$ & $\begin{array}{l}\mathrm{SdW}=1 \mathrm{E}-02 \mathrm{SL}^{2.60} \\
\mathrm{r}=0.93 \mathrm{t}=31.96\end{array}$ & $\begin{array}{l}\mathrm{SdW}=5 \mathrm{E}-03 \mathrm{SL}^{2.42} \\
\mathrm{r}=0.91 \mathrm{t}=20.02\end{array}$ \\
\hline FdW/SL & $\begin{array}{c}\mathrm{FdW}-\mathrm{f}=1 \mathrm{E}-05 \mathrm{SL}^{2.96} \\
\mathrm{r}=0.87 \mathrm{t}=7.80\end{array}$ & $\begin{array}{c}\mathrm{FdW}-\mathrm{f}=5 \mathrm{E}-06 \mathrm{SL}^{3.22} \\
\mathrm{r}=0.88 \mathrm{t}=13.09\end{array}$ & $\begin{array}{c}\mathrm{FdW}-\mathrm{f}=8 \mathrm{E}-05 \mathrm{SL}^{2.52} \\
\mathrm{r}=0.77 \mathrm{t}=117.62\end{array}$ & $\begin{array}{c}\mathrm{FdW}-\mathrm{f}=3 \mathrm{E}-05 \mathrm{SL}^{2.73} \\
\mathrm{r}=0.79 \mathrm{t}=64.42\end{array}$ \\
\hline
\end{tabular}

bryozoans, sipunculids, and green and brown algae (Table 2).

\section{Epibiotic species associated with $\mathrm{S}$. haemastoma}

The associated community removed from the external shell surface of the basibiont is compiled in Table 2 , and some photos of the epibiotic species are depicted in Figure 2 (A - E). Among the epibiotic taxa, barnacles were the most represented group (Fig. 2C) and were fixed mainly on the dorsal left face of the apical part of the shell (Fig. 3A). The number of barnacles per host was $23.2 \pm 16.5$, against $2.3 \pm 2.8$ for the oysters, which were randomly distributed on the gastropod shell (Fig. 2D). The shell surface also showed the presence of scattered U-shapped tubes that sheltered sedentary polychaetes (Fig. 3B), with Serpulidae and Sabellidae being the most abundant polychaete families (Table 2). Regarding errant polychaetes, the gastropod shell was generally colonized by the families Syllidae, Eunicidae, Nereidae, Phyllodocidae, Chrysopetalidae and Sphaerodaridae (Table 2).

\section{Endobiotic species associated with $\mathrm{S}$. haemastoma}

Following shell breakage, a rich endofauna was detected living in breaches, tunnels or galleries dug by annelids, lithophagous bivalves, sipunculids and crustaceans. The last two groups (sipunculids and crustaceans) were less represented than annelids (sedentary and errant polychaetes), which were found in $65.6 \%$ of the gastropods, with an average of $3.4 \pm 2.7$ annelids per host. Polychaetes burrowing the shell of $S$. haemastoma at different positions are shown in Figure 2 (F-H). Tunnels perforated by these polychaetes sheltered errant annelids such as Aponuphis bilineata (Fig. 2I-J) and Perinereis cullrifera (Fig. 2K). The lithophagous bi- valves Lithophaga aristata and Rocellaria dubia were extracted from breaches having the same size and form as the endobiont. L. aristata (4 to $17.5 \mathrm{~mm}$ in length) was found in $10.1 \%$ of the gastropods examined and occupied galleries situated mainly at the dorsal side of the shell (Fig. 2L), in the direction "apical axis-siphonal canal" (Fig. 2M, N) or in perpendicular direction (Fig. 2O-R). The preferential colonization zone of $L$. aristata in the shell of $S$. haemastoma is schematically illustrated in Figure 3C. In contrast, $R$. dubia $(6.6 \mathrm{~mm}$ in length) occurred at a very low rate $(0.1 \%)$ and was removed from breaches dug in the last spire of the host shell (Fig. 2S, T). Five specimens of sipunculids were found in tunnels and galleries belonging to the families Phascolosomatidae (three Phascolosoma stephensoni of 10, 13 and $16 \mathrm{~mm}$ length and one Phascolosoma sp. of $13.5 \mathrm{~mm}$ length) (Fig. 2U) and Aspidosiphonidae (Aspidosiphon muelleri muelleri of $11 \mathrm{~mm}$ long) (Fig. $2 \mathrm{~V})$. One specimen of $P$. stephensoni was found in a gallery located on the edge of the columella (Fig. 2W), while all other individuals were removed from tubes dug in the dorsal face nearby the apex of the shell. An unidentified crustacean (Acrothoracica sp.) was found in an intra-shell cavity of $3 \mathrm{~mm}$ (Fig. 2X).

\section{Relative growth}

Stramonita haemastoma fouled by epibiotic barnacles (GFB) displayed negative allometry for the relationships SD/SL, SdW/SL and FdW/SL, indicating that in both sexes SL grows at a faster rate than SD, SdW and FdW. On the other hand, S. haemastoma non-fouled by barnacles (GnFB) showed a higher growth of SD and FdW than of SL (Table. 3). The ANCOVA test detected significant differences between GFB and GnFB for the relationships SD/SL and FdW/SL (Table 4).

Table 4. - Results of the ANCOVA performed with data on relative growth of S. haemastoma. SL, shell length; SD, shell diameter; SdW, Shell dry weight; FdW, Flesh dry weight: GFB, gastropods fouled by barnacles; GnFB, gastropods non-fouled by barnacles.

\begin{tabular}{|c|c|c|c|c|c|c|}
\hline \multirow[t]{2}{*}{ Biometric variables } & \multicolumn{2}{|c|}{$\mathrm{SD} / \mathrm{SL}$} & \multicolumn{2}{|c|}{$\mathrm{SdW} / \mathrm{SL}$} & \multicolumn{2}{|c|}{$\mathrm{FdW/SL}$} \\
\hline & $\mathrm{F}$ & $\mathrm{P}$ & $\mathrm{F}$ & $\mathrm{P}$ & $\mathrm{F}$ & $\mathrm{P}$ \\
\hline Total GnFB vs GFB & 1.51 & 0.21 & 5.19 & 0.02 & 40.65 & $<0.01$ \\
\hline GnFB: Males vs Females & 0.36 & 0.54 & 4.74 & 0.03 & 7.13 & $<0.01$ \\
\hline GFB: Males vs Females & 0.24 & 0.62 & 2.22 & 0.13 & 46.24 & $<0.01$ \\
\hline
\end{tabular}



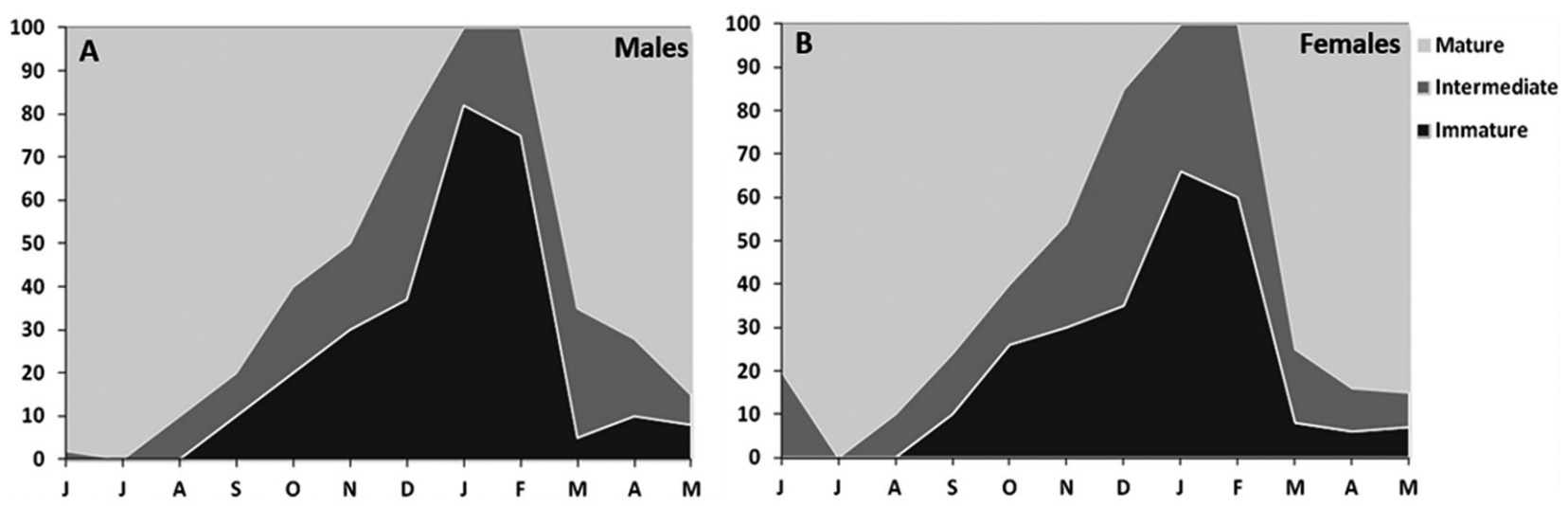

Fig. 4. - Monthly variation of gonad maturation stages in males (A) and females (B) of S. haemastoma, following macroscopic observation of the reproductive organs.
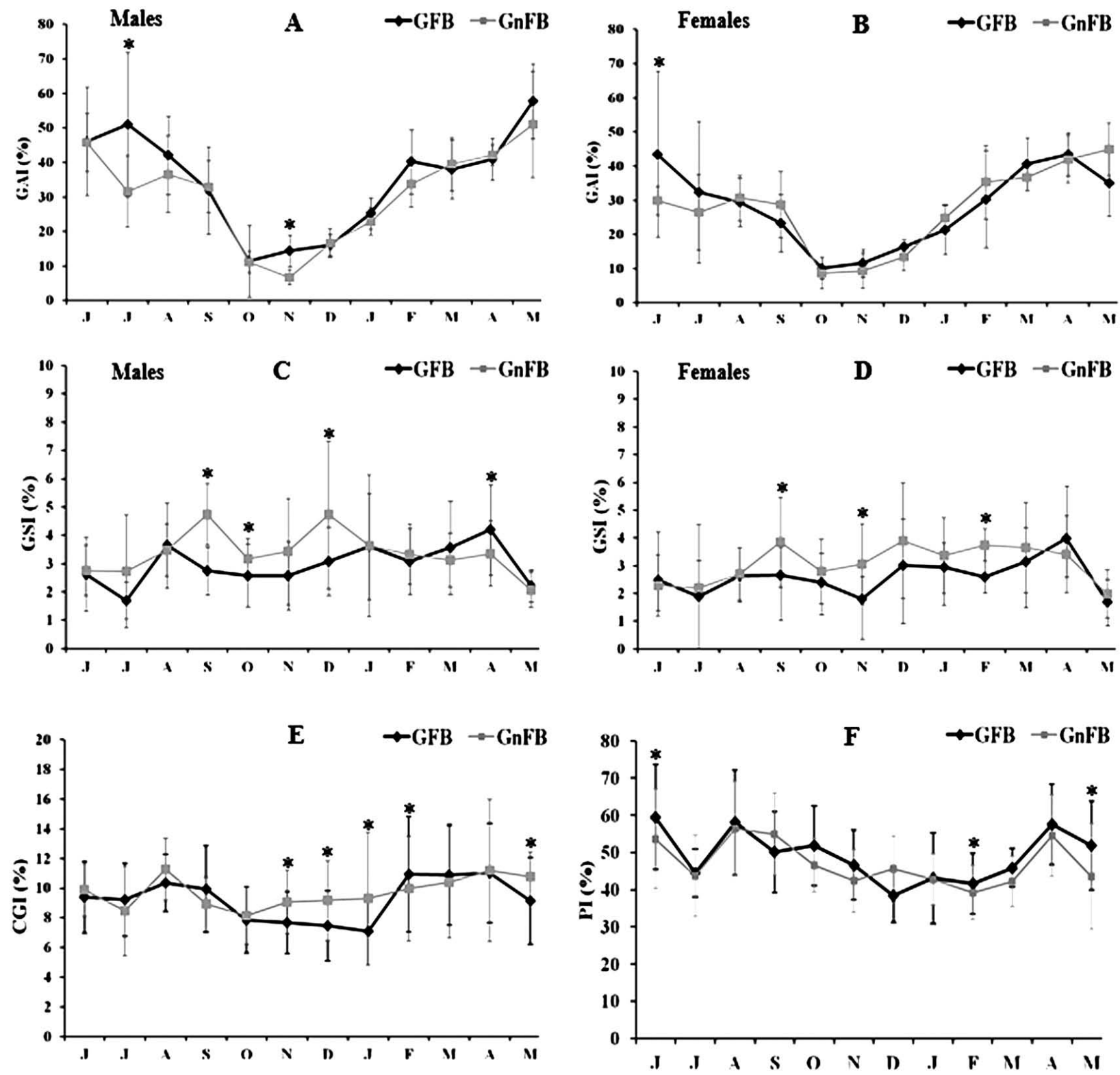

Fig. 5. - Comparison of the monthly variation of the gonad area index (GAI) in males (A) and females (B); gonadosomatic index (GSI) in males (C) and females (D); capsule gland index (CGI) (E) and penial index (PI) (F) in S. haemastoma non-fouled (GnFB) and fouled (GFB) by epibiotic barnacles (June 2009 - May 2010). (*) Statistically significant differences GnFB and GFB in each month. 
Taking into consideration the sex, both males and females fouled by epibiotic barnacles showed negative allometries in the relationships SD/SL, SdW/SL and FdW/SL, indicating that shell grows faster in length than in diameter, SdW and FdW. This type of allometry was also recorded in non-fouled males for the relationships SdW/SL and FdW/SL. For the relationship SD/SL isometry was recorded in both sexes for the relationship SdW/SL it was recorded in non-fouled females. As for the relationship FdW/SL, positive allometry was detected, indicating higher growth in flesh weight than in shell length (Table. 3). Statistically significant differences between males and females occurred in the relationships FdW/SL for GFB and SdW/ SL and FdW/SL for GnFB (Table 4).

\section{Reproductive cycle}

Macroscopic observations of the gonads of $S$. haemastoma showed a great similarity in the rhythm of gonad maturation between males and females (Fig. $4 \mathrm{~A}, \mathrm{~B}$ ), with mature males and females being present throughout the year, except in January and February, when only immature and intermediate individuals were recorded (Fig. 4A, B). Gonadal maturation occurred from May-June to October. The highest percentages of ripe gonads were recorded in July (100\%) in both males and females (Fig. 4A, B), with a period of gametogenesis extending from December to April-May (Fig. 4A, B). Once gametes were mature, copulation and capsule deposition occurred about seven days later. All three gonad maturation stages were found almost year-round, except for the absence of stage I (immature) in June, July and August, stage II (intermediate) in July and stage III (mature) in January and February (Fig. 4).

Monthly variations in the reproductive condition indices of $S$. haemastoma during the study period are presented in the Figure 5. All indices showed similar trends in males and females, with slight variations in some months. The GAI showed that gametogenesis occurred from November to April-May. After that, spawning took place between June-July and October. In fouled snails, spawning was significant during this period, while it occurred mainly in September in nonfouled snails. Significant differences between lots were detected during June in males, and during July and November in females, when the highest values of GAI were recorded in GFB (males: $\mathrm{H}=0.12, \mathrm{P}<0.05$; females: $\mathrm{H}=0.16, \mathrm{P}<0.05$ ) (Fig. 5A, B).

GSI values displayed more fluctuations than GAI values and were more regular in fouled snails. GnFB displayed three decreasing periods in GSI, with two periods (from September to October and from April to July) probably being associated with spawning, and the third one, from December to February, which was due to another unknown activity. Decreases of the index were displayed in GFB from August to September (in males) and October-November (in females) and from April to July in both sexes (Fig. 5C, D). Significant differences were recorded between lots in September, October, December and April for males and in Novem- ber, February and April for females (males: $\mathrm{H}=18.23$, $\mathrm{P}<0.05$; females: $\mathrm{H}=30.13, \mathrm{P}<0.05$ ).

The monthly variation in the CGI showed that hypertrophy of glands was reached in February and continued until August in both female lots. Atrophied capsule glands were observed from October to January, indicating that spawning occurred between August and October. The values of CGI showed that the capsule gland in GnFB was bigger than that in GFB in August, November, December, January and May $(\mathrm{H}=7.38$, $\mathrm{P}=0.006$ ) (Fig. 5E).

The PI showed that penis hypertrophy is reached in April, while it becomes atrophied in NovemberDecember. Copulation occurred between June and July and between August-September (in GFB) and September-November (in GnFB). The Kruskal-Wallis test $(\mathrm{H}=4.98, \mathrm{P}=0.025)$ showed significant differences in May and June in favour of GFB and in December in favour of GnFB (Fig. 5F).

\section{DISCUSSION}

The present study has shown that the shell of live S. haemastoma collected from Bizerta Channel is a suitable biotope for several invertebrate species. The most abundant epibiotic species were barnacles that totally covered the shell of several snails. Sedentary polychaetes and lithophagous bivalves were the most abundant endobiotic species. For polychaetes, a prevalence of cirratulids especially represented by Dodecaceria concharum was recorded. In S. haemastoma from the Spanish coast, the shell of live individuals sheltered, in addition to $D$. concharum, three other species, namely Dipolydora armata, Capitella minima and Spirobranchus polytrema (Bick 2006). Seven families of polychaetes found in the present study (Spionidae, Ciratulidae, Syllidae, Nereidae, Sabellidae, Sabellariidae and Serpulidae) were also reported in H. trunculus from Portuguese waters by Vasconcelos et al. (2007). These authors showed that the dorsal surface of the shell, mainly in the proximity of the apex, was generally more fouled by epibiotic polychaetes than the ventral surface, a pattern of colonization which is in agreement with the present results and that is probably related to the mode of locomotion of this snail. Indeed, it has been shown that $S$. haemastoma moves by crawling on hard substrate and by burrowing on soft substrate when the rocks become exposed during low tides (Papp and Duarte 2001). In both cases, the continuous abrasion of the ventral surface leads to an erosion of the settled epibionts, with the same finding being also recorded in H. trunculus (Vasconcelos et al. 2007).

Fouling is likely to be a function of time, food availability, seawater salinity and temperature (Wahl 1989, Sahu et al. 2013). In fact, it has been shown that salinity influences all physical-chemical variables of seawater and controls the larval dispersal and recruitment patterns of epi- and endobiotic species (Nair 1965), while seawater temperature influences chemical and biological interaction and regulates the growth of benthic organisms (Sahu et al. 2013). Consequently, the shells of smaller gastropods are usually less colonized 
by epifauna than those of larger gastropods, which also agrees with our observations. Abundant colonization could have serious and deleterious consequences on the basibiont. Indeed, Thieltges and Buschbaum (2007) and Buschbaum et al. (2007) showed that the presence of the worm Polydora ciliata on the shell of Littorina littorea facilitates barnacle fixation, leads to a gradual destruction of the shell, reduces the resistance against predators and reduces the fecundity and the growth of the gastropods. According to Lleonart et al. (2003), an infestation of $30 \%$ in the gastropod Haliotis spp. from the Australian coast by two spionid species (Boccardia knoxi and Polydora hoplura) leads to the mortality of half of the affected population.

For endofauna, we recorded the presence of $L$. aristata and $R$. rubia, with infestation rates of $10.1 \%$ and $0.1 \%$, respectively. Trigui El Menif et al. (2007) isolated those two boring mytilids from the rock hosting L. lithophaga collected in the Bay of Bizerta. Rocellaria dubia was also found by the same authors in breaches dug in the shell of live Venus verrucosa. Tebble (1976) reported the presence of $R$. dubia in various substrates (sand, limestone, sandstone and dead mollusc shells) but not in live specimens. This bivalve, as well as the other lithophagous species, has a pair of pallial glands that secrete a calcium-binding mucoprotein for boring into calcareous organisms (Jaccarini et al. 1968). The continuous growth of the endobiont involves a growth in the volume of the breach causing a progressive perforation of the shell of the basibiont, which in some cases leads to its death. This finding was recorded by Simone and Gonçalves (2006) and by Trigui El Menif et al. (2006), respectively in Nodipecten nodosus infested by L. aristata and in V. verrucosa infested by Rocellaria dubia. With regard to our results, the infestation of S. haemastoma by L. aristata does not seem to act negatively on the gastropod at this level, because the extracted endobiont had a size of $17 \mathrm{~mm}$ in length and $6 \mathrm{~mm}$ in thickness, which does not exceed either the length or the thickness of the gastropod columella. Negative effects in the basibiont could probably occur with the progressive growth of the endobiont, since $L$. aristata can attain a length of $52 \mathrm{~mm}$ (Turner and Boss 1962). According to Simone and Gonçalves (2006), the geographical distribution of the L. aristata is probably limited to the Atlantic coasts. Moreover, Ávila et al. (2009) discovered L. aristata as a fossil form on the island of Santa Maria (Azores). The presence of this species in Tunisian coasts, in the same habitat as $L$. lithophaga (Trigui El Menif et al. 2006) and in the shell of $S$. haemastoma, lets us suppose that it is an invasive species coming from the Strait of Gibraltar.

A male-biased sex ratio was found in S. haemastoma from Bizerta Channel, which agrees with previous studies on this species that concluded that this could be due to either female mortality or imposex in some females (Rilov 1999). Usually, differences in growth between populations collected from different sites are associated with many factors, including environmental conditions, TBT pollution, prey type and parasitism (Crothers 1985). Another factor that seems to affect the growth of gastropods is biofouling, since non-fouled and fouled gastropods were collected at the same sampling site. Indeed, the annual growths in terms of SD and FdW were higher in non-fouled gastropods. In fact, biofouling is time-dependent (Wahl 1989), which means that the growth of S. haemastoma is also accompanied by an increase in number and size of epibiotic barnacles. In some cases the weight of the barnacles per gastropod host is equal to its own weight; this most probably has negative effects on locomotion of snails, which must move between different substrates in order to feed, avoid unfavourable environmental conditions and escape predation. Consequently, gastropods fouled by epibiotic barnacles spend more energy during their movements at the expense of their growth than nonfouled gastropods. Indeed, it has been demonstrated that epibiotic barnacles in L. littorea decrease the locomotion and consequently the growth of gastropods (Buschbaum and Reise 1999, Thieltges and Buschbaum 2007). Thieltges and Buschbaum (2007) also showed that epibiotic Crepidula fornicata reduces the growth and survival of blue mussels (Mytilus edulis). Recently, Lacoste et al. (2014) recorded that biofouling reduces the growth of pearl oysters (Pinctada margaritifera) in French Polynesia. Our results showed that non-fouled females of $S$. haeamstoma have heavier shells and flesh. In contrast, Lahbib (2004) found that males of Hexaplex trunculus have heavier shells and flesh than females, considering this as sexual dimorphism characterizing specimens collected from Menzel Jemil (northern Tunisia).

The study of the reproductive cycle of S. haemastoma from the Tunisian coast showed an acceptable agreement between the macroscopic classification of gonad maturation stages and three of the bio-physiological indices used (GAI, CGI and PI). In contrast, the GSI showed significant fluctuations that could not be directly related to the reproductive cycle of $S$. haemastoma. This index is probably influenced by other factors, such as variations in the weight of the digestive gland after food ingestion and also SdW, because it is sometimes difficult to entirely remove all epibionts from the basibiont shell. Therefore, based on this result it would be more suitable to follow the reproductive activity of $S$. haemastoma using macroscopic observations together with GAI, CGI and PI. The simultaneous increase in GAI and decrease in CGI indicate gonad maturation and the beginning of spawning in May, which were probably triggered by an abrupt increase in seawater temperature, from $17^{\circ} \mathrm{C}$ in April to $23.9^{\circ} \mathrm{C}$ in May, with a similar finding being recorded in $B$. brandaris from Tunisian waters (Abidli el al. 2012). Vasconcelos et al. (2008) and Elhasni et al. (2010) recommended the use of two indices (GAI and CGI) and considered them simple, practical and efficient for the routine assessment of reproductive activity in a sympatric muricid (H. trunculus). Abidli et al. (2012), Vasconcelos et al. (2012) and Elhasni et al. (2013) confirmed these findings in analogous studies with another sympatric muricid (B. brandaris). Usually, differences in the reproductive cycle are explained by variation in seawater temperature (Lahbib et al. 2009, Abidli et al. 2012). Another factor that seems to affect the repro- 
ductive activity of gastropods is imposex (Lahbib et al. 2009). Results gathered in this study further suggest that the reproductive cycle of $S$. haemastoma is also affected by biofouling. Furthermore, Vasconcelos et al. (2011) established the PI for the study of the reproductive activity of male $H$. trunculus. This index was also practical for the study of the reproductive activity of male $S$. haemastoma, but must be used cautiously at sites highly affected by TBT pollution, such as Bizerta Channel (Lahbib et al. 2011), because it has been shown that TBT contamination might increase male PL (Castro et al. 2007, Abidli et al. 2013).

\section{ACKNOWLEDGEMENTS}

We would like to thank the anonymous reviewers for their valuable comments and suggestions to improve the overall quality of the manuscript. We are also grateful to the editor for the effort in compiling and accommodating the reviewers' comments and suggestions.

\section{REFERENCES}

Abidli S., Lahbib Y., Trigui El Menif N. 2012. Relative growth and reproductive cycle in two populations of Bolinus brandaris (Gastropoda: Muricidae) from northern Tunisia (Bizerta Lagoon and small Gulf of Tunis). Biologia 67: 751-761. http://dx.doi.org/10.2478/s11756-012-0060-7

Abidli S., Lahbib Y., Rodríguez González P., et al. 2013. Imposex and butyltin burden in Bolinus brandaris (Mollusca, Gastropoda) and sediment from the Tunisian Coast. Hydrobiologia 714: 13-24. http://dx.doi.org/10.1007/s10750-013-1505-x

Ávila S.P., Madeira P., Zazo C., et al. 2009. Palaeoecology of the Pleistocene (MIS 5.5) outcrops of Santa Maria Island (Azores) in a complex oceanic tectonic setting. Palaeogeogr. Palaeoclimatol. Palaeoecol. 274: 18-31. http://dx.doi.org/10.1016/j.palaeo.2008.12.014

Beliste B.W., Stickle W.B. 1978. Seasonal patterns in the biochemical constituents and body component indexes of the Muricid Gastropod, Thais haemastoma. Biol. Bull. 155: 259-272. http://dx.doi.org/10.2307/1540951

Bick A. 2006. Polychaete communities associated with gastropod shells inhabited by the hermit crabs Clibanarius erythropus and Calcinus tubularis from Ibiza, Mediterranean Sea. J. Mar. Biol. Ass U.K. 86: 83-92. http://dx.doi.org/10.1017/S0025315406012884

Buschbaum C., Reise K. 1999. Effects of barnacle epibionts on the periwinkle Littorina littorea (L.). Helgol. Mar. Res. 53: 56-61. http://dx.doi.org/10.1007/PL00012138

Buschbaum C., Buschbaum G., Schrey I., et al. 2007. Shell-boring polychaetes affect gastropod shell strength and crab predation. Mar Ecol Prog Ser. 329: 123-130. http://dx.doi.org/10.3354/meps329123

Castro L.F.C., Lima D., Machado A., et al. 2007. Imposex induction is mediated through the Retinoid X Receptor signalling pathway in the neogastropod Nucella lapillus. Aquat. Toxicol. 85: 57-66. http://dx.doi.org/10.1016/j.aquatox.2007.07.016

Crothers J. H. 1985. Dogwhelks: an introduction to the biology of Nucella lapillus. Field Stud. 6: 291-360.

Duault C., Gillet P., Fleury P.G. 2001. Evolution spatio-temporelle de l'infestation des huitres creuses, Crassostrea gigas, par les vers du genre Polydora (Annelides Polychetes), dans le cadre du reseau Remora d'Ifremer. J. Res. Oceanogr. 26(3):136.

El Ayari T., Abidli S., Lahbib Y., et al. 2015. The effect of size and epibiotic barnacles on imposex in Stramonita haemastoma collected from the northern coast of Tunisia. Mar. Biol. Res. 11: 313-320. http://dx.doi.org/10.1080/17451000.2014.914223

Elhasni K., Ghorbel M., Vasconcelos P., et al. 2010. Reproductive cycle and size at first sexual maturity of Hexaplex trunculus (Gastropoda: Muricidae) in the Gulf of Gabès (southern Tuni- sia). Invertebr. Reprod. Dev. 54: 213-225. http://dx.doi.org/10.1080/07924259.2010.9652335

Elhasni K., Vasconcelos P., Ghorbel M., et al. 2013. Reproductive cycle of Bolinus brandaris (Gastropoda: Muricidae) in the Gulf of Gabès (southern Tunisia). Medit. Mar. Sci. 14: 24-35. http://dx.doi.org/10.12681/mms.325

Giménez J., Penchaszadeh P.E. 2003. Size at first sexual maturity in Zidona dufresnei (Caenogastropoda:Volutidae) of the southwestern Atlantic Ocean (Mar del Plata, Argentina). J. Mar. Biol. Ass. U.K. 83: 293-296. http://dx.doi.org/10.1017/S0025315403007100h

Jaccarini V., Bannister W.H., Micallef H. 1968. The pallial glands and rock boring in Lithophaga lithophaga (Lamellibranchia, Mytilidae). J. Zool. 154: 397-401 http://dx.doi.org/10.1111/j.1469-7998.1968.tb01672.x

Keough M.J. 1984. Dynamics of the epifauna of the bivalve Pinna bicolor: Interactions among recruitment, predation, and competition. Ecol. Soc. Am. 65: 677-688. http://dx.doi.org/10.2307/1938040

Lacoste E., Le Moulla G., Levy P., et al. 2014. Biofouling development and its effect on growth and reproduction of the farmed pearl oyster Pinctada margaritifera. Aquaculture 434: 18-26.

Lahbib Y. 2004. Impact des conditions du milieu sur la biologie du rocher fascié Hexaplex trunculus prélevé dans la lagune et le canal de Bizerte. Master, Fac. Sc. Bizerte, 72 pp.

Lahbib Y, Abidli S., Trigui El Menif N. 2009. Relative growth and reproduction in Tunisian populations of Hexaplex trunculus with contrasting imposex levels. J. Shellfish. Res. 28: 891-898. http://dx.doi.org/10.2983/035.028.0419

Lahbib Y, Abidli S, Chiffoleau JF, et al. 2010. Imposex and butyltin concentrations in snails from the lagoon of Bizerta (Northern Tunisia). Mar. Biol. Res. 6: 600-607. http://dx.doi.org/10.1080/17451000903437075

Lahbib Y., Abidli S., Trigui El Menif N. 2011. Spawning and intracapsular development of Stramonita haemastoma haemastoma (Gastropoda: Muricidae) collected in northern Tunisia. Mar. Biol. Res. 7: 1-8. http://dx.doi.org/10.1080/17451000.2011.558099

Lemghich I., Benajiba M.H. 2007. Survey of imposex in prosobranch mollusks along the northern Mediterranean coast of Morocco. Ecol. Indic. 7: 209-214. http://dx.doi.org/10.1016/j.ecolind.2005.09.007

Lleonart M., Handlinger J., Powell M. 2003. Spionid mudworm infestation of farmed abalone (Haliotis spp.). Aquaculture 221: 85-96. http://dx.doi.org/10.1016/S0044-8486(03)00116-9

Lucas A., Beninger P.G. 1985. The use of physiological condition indices in marine bivalve aquaculture. Aquaculture 44: $187-200$. http://dx.doi.org/10.1016/0044-8486(85)90243-1

Mayrat A. 1959. Nouvelle méthode pour l'étude comparée d'une croissance relative dans deux échantillons. Application à la carapace de Penaeus kerathurus. Inst. Franc. Afr. Noire. 21: 21-59.

Nair N.V. 1965. Marine fouling in Indian waters. J. Mar. Biol. Ass. U.K. 24: 483-488.

Papp M.G., Duarte L.F.L. 2001. Locomotion of Stramonita haemastoma (Linnaeus) (Gastropoda, Muricidae) on a mixed shore of rocks and sand. Rev. Bras. Zool. 18: 187-195. http://dx.doi.org/10.1590/S0101-81752001000100022

Poore G.C.B. 1973. Ecology of New Zealand abalones, Haliotis species (Mollusca: Gastropoda). N. Z. J. Mar. Freshw. Res. 7: 67-84. http://dx.doi.org/10.1080/00288330.1973.9515456

Rabaoui L., Tlig-Zouari S., Cosentino A., et al. 2009. Associated fauna of the fan shell Pinna nobilis (Mollusca: Bivalvia) in the northern and eastern Tunisian coasts. Sci. Mar. 73: 129-141. http://dx.doi.org/10.3989/scimar.2009.73n1129

Ramón M., Amor M.J. 2002. Reproductive cycle of Bolinus brandaris and penis and 494 genital duct size variations in a population affected by imposex. J. Mar. Biol. Assoc. UK. 82: 435-442. http://dx.doi.org/10.1017/S0025315402005696

Rilov G. 1999. The whelk Stramonita haemastoma in the Eastern Mediterranean rocky littoral: Biotic and abiotic perspectives. $\mathrm{PhD}$ thesis, Tel-Aviv. Univ. Tel-Aviv, $234 \mathrm{pp}$.

Sahu G., Satpathy K.K., Mohanty A.K., et al. 2013. Larval abundance and its relation to macrofouling settlement pattern in the coastal waters of Kalpakkam, southeastern part of India. Environ. Monit. Assess. 185: 1951-1967. http://dx.doi.org/10.1007/s10661-012-2679-9 
Schejter L., Bremec C.S. 2006. Epibionts on Flexopecten felipponei (Dall, 1922), an uncommon scallop from Argentina. Am. Malacol. Bull. 22: 75-82. http://dx.doi.org/10.4003/0740-2783-22.1.75

Simone L.R.L., Gonçalves E.P. 2006. Anatomical study on Myoforceps aristatus, an invasive boring bivalve in S.E. Brazilian coast (Mytilidae). Pap. Avulsos. Zool (São Paulo) 46: 57-65. http://dx.doi.org/10.1590/S0031-10492006000600001

Spence S.K., Hawkins S.J., Santos R.S. 1990. The mollusc Thais haemastoma - an exhibitor of 'imposex' and potential biological indicator of tributyltin pollution. Mar. Ecol. 11: 147-156. http://dx.doi.org/10.1111/j.1439-0485.1990.tb00235.x

Tebble N. 1976. British Bivalve Seashells. Trustees of the British Museum Natural History. (Second Edition). Her Majesty Stationery Office, Edinburgh, $212 \mathrm{pp}$.

Terlizzi A., Fraschetti S., Gianguzza P., et al. 2001. Environmental impact of antifouling technologies: state of the art and perspectives. Aquat. Conserv. Mar. Freshw. Ecosyst. 11: 311-317. http://dx.doi.org/10.1002/aqc.459

Thieltges D.W., Buschbaum C. 2007. Vicious circle in the intertidal: Facilitation between barnacle epibionts, a shell boring polychaete and trematode parasites in the periwinkle Littorina littorea. J. Exp. Mar. Biol. Ecol. 340: 90-95. http://dx.doi.org/10.1016/j.jembe.2006.08.014

Trigui El Menif N., Guezzi Y., Le Pennec M., et al. 2005. Infestation of the clam Venus verrucosa by Sipunculoidea and the lithophagus bivalve, Gastrochaena dubia. Acta. Adriat. 46: 83-90.

Trigui El Menif N., Lahbib Y., Le Pennec M., et al. 2006. Intensity of the imposex phenomenon - impact on growth and fecundity in Hexaplex trunculus (Mollusca: Gastropoda) collected in Bizerta lagoon and Channel (Tunisia). Cah. Biol. Mar. 47: 165-175.

Trigui El Menif N., Jaafar Kefi F., Ramdani M., et al. 2007. Habitat and associated fauna of Lithophaga lithophaga (Linneus 1758) in the bay of Bizerta (Tunisia). J. Shellfish Res. 26: 569-574. http://dx.doi.org/10.2983/0730-8000(2007)26[569:HAAFOL] 2.0.CO;2

Turner R.D., Boss K.J. 1962. The genus Lithophaga in the western Atlantic. Johnsonia 4: 81-116.

Vasconcelos P., Cúrdia J., Castro M., et al. 2007. The shell of Hexaplex (Trunculariopsis) trunculus (Gastropoda: Muricidae) as a mobile hard substratum for epibiotic polychaetes (Annelida: Polychaeta) in the Ria Formosa (Algarve coast-southern Portugal). Hydrobiologia 575: 161-172. http://dx.doi.org/10.1007/s10750-006-0367-x

Vasconcelos P., Lopes B., Castro M., et al. 2008. Gametogenic cycle of Hexaplex (Trunculariopsis) trunculus (Gastropoda: Muricidae) in the Ria Formosa lagoon (Algarve coast - southern Portugal). J. Mar. Biol. Ass. U.K. 88: 321-329. http://dx.doi.org/10.1017/S0025315408000593

Vasconcelos P., Moura P., Castro M., et al. 2011. Size matters: importance of penis length variation on reproduction studies and imposex monitoring in Bolinus brandaris (Gastropoda: Muricidae). Hydrobiologia 661: 364-375. http://dx.doi.org/10.1007/s10750-010-0544-9

Vasconcelos P., Moura P., Barroso C.M., et al. 2012. Reproductive cycle of Bolinus brandaris (Gastropoda: Muricidae) in the Ria Formosa lagoon (southern Portugal). Aquat. Biol. 16: 69-83. http://dx.doi.org/10.3354/ab00434

Wahl M. 1989. Marine epibiosis. I. Fouling and antifouling: some basic aspects. Mar. Ecol. Prog. Ser. 58: 175-189. http://dx.doi.org/10.3354/meps058175

Ward M.A., Thorpe J.P. 1991. Distribution of encrusting bryozoans and other epifauna on the subtidal bivalve Chlamys opercularis. Mar. Biol. 110: 253-259. http://dx.doi.org/10.1007/BF01313711 